\title{
Is inotropic therapy appropriate for patients with chronic congestive heart failure? Or is the digitalis leaf withering?
}

\author{
Barry F. Uretsky \\ Division of Cardiology, University of Pittsburgh School of Medicine and Presbyterian-University Hospital, \\ Pittsburgh, PA 15213, USA.
}

\begin{abstract}
Summary: The appropriateness of inotropic therapy in chronic heart failure was examined by critically reviewing five assumptions upon which this form of therapy has been justified. Only the first, that cardiac performance can be acutely improved by inotropic therapy, has been empirically proven. That such acute improvement is sustained appears to be true with non-catecholamine agents whereas the chronic haemodynamic efficacy of oral catecholamines remains in doubt. That any inotropic agent can improve exercise tolerance, make the patient feel better, or effect a change without deleteriously affecting the myocyte is very much in doubt. Thus, although the prospect of using powerful inotropic therapy in the patient with heart failure is theoretically appealing, its utility remains to be proven.
\end{abstract}

With the historical precedent of digitalis, the propriety for using an inotropic agent in chronic heart failure has, by and large, not been seriously questioned. The logic seems clear in directing therapy at the central derangement in most types of heart failure, namely myocardial dysfunction. That a positive inotropic agent can be effective therapy in chronic heart failure has not, however, been proven. The use of such agents is predicated on certain assumptions which may not be correct. These assumptions will be examined in order to consider the possible therapeutic role of inotropic therapy in chronic heart failure.
Many compounds have been shown to possess positive inotropism in isolated cardiac muscle preparations (Table I). Interestingly, most of these agents, particularly those in use or under active investigation, also demonstrate vasoactive properties. For example, the beta-1 agonist dobutamine may also produce vasodilatation by beta- 2 stimulation and alphaadrenergic antagonistic actions of its $(+)$ isomer (Ruffolo et al., 1981). It may also produce vasoconstriction by an alpha-adrenergic action of the $(-)$ isomer (Ruffolo et al., 1981). The blood pressure response is thus a summation of its multiple vasoactive

Table I A partial list of positive inotropes with a peripheral vascular action

\begin{tabular}{lll}
\hline Drug & Cardiac mechanism of action & Peripheral vascular response \\
\hline $\begin{array}{l}\text { Amrinone, milrinone } \\
\text { Digoxin }\end{array}$ & $\begin{array}{l}\text { Phosphodiesterase inhibition } \\
\text { Inhibition of sodium-potassium } \\
\text { ATPase pump } \\
\text { Beta-1 stimulation }\end{array}$ & $\begin{array}{c}\text { Vasodilatation } \\
\text { Vasoconstriction }\end{array}$ \\
$\begin{array}{lll}\text { Dobutamine } & \text { Beta-1 stimulation } & \text { (+) Isomer; vasodilatation (beta-2 } \\
\text { stimulation; alpha antagonist) } & \text { (-) Isomer; vasoconstriction (alpha } \\
\text { stimulation) }\end{array}$ \\
$\begin{array}{ll}\text { Vasodilatation of renal and mesenteric } \\
\text { beds (low dose, dopaminergic receptor) }\end{array}$ \\
$\begin{array}{l}\text { MDL 17,043; MDL 19,205 } \\
\text { Pirbuterol, prenalterol, salbutamol }\end{array}$ & $\begin{array}{c}\text { Phosphodiesterase inhibition } \\
\text { Beta-1 stimulation }\end{array}$ & $\begin{array}{c}\text { Stimulation) } \\
\text { Vasodilatation } \\
\text { Vasodilatation (beta-2-stimulation) }\end{array}$ \\
\hline
\end{tabular}

Correspondence: B.F. Uretsky, M.D., Cardiac Diagnostic Laboratories, 3494 Presbyterian-University Hospital, DeSoto \& O'Hara Streets, Pittsburgh, PA 15213, USA. 
as well as its cardioactive properties (Figure 1). The digitalis compounds may produce, at least acutely, regional vasoconstriction (Mason, 1974) and the experimental inotropic agents amrinone (Ross et al., 1981; van Breeman et al., 1980), milrinone (Alousi et al., 1983) and MDL 17,043 (Uretsky et al., 1983) produce regional vasodilation.

With the caveat in mind that demonstrated effects in man may be related to the vasoactive as well as cardioactive effects of a drug, we shall examine whether certain assumptions under which these agents have been clinically used or investigated are justified.

Assumption 1 That a contractile reserve exists in patients with heart failure that may be tapped by an inotropic agent.

Multiple clinical studies have justified this assumption (Table II). Dobutamine (Leier et al., 1977), dopamine (Beregovich et al., 1974; Loeb et al., 1971; Holzer et al., 1973), amrinone (Benotti et al., 1978; LeJemtel et al., 1979; Maskin et al., 1982), milrinone (Sinoway et al., 1983; Maskin et al., 1983a; Baim et al., 1983), MDL 17,043 (Uretsky et al., 1983), MDL 19,205 (Petain et al., 1984) and ARL-115-BS (Renard et al., 1983; Thormann et al., 1982), among others have been shown to improve haemodynamics acutely in patients with chronic severe (New York Heart Association Class III-IV) heart failure. Such improvement may occur even with drugs that act by a beta-adrenergic mechanism which may already have been endogenously stimulated (Figure 2).

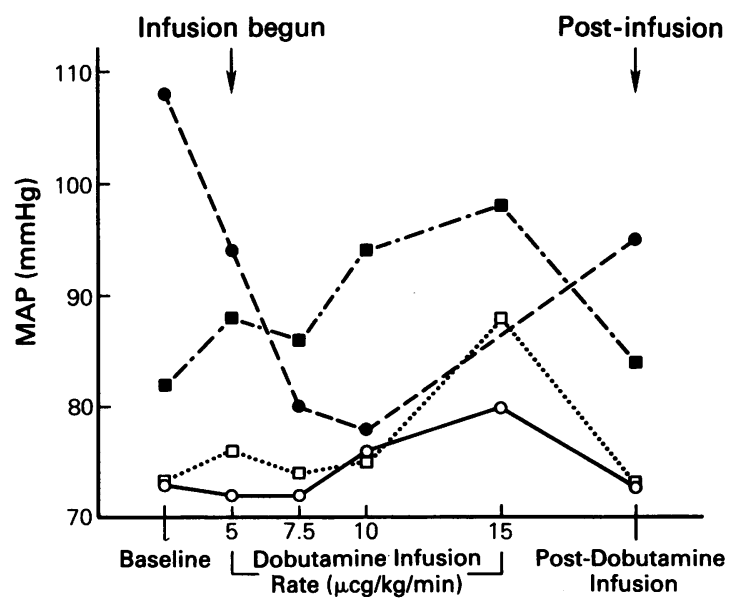

Figure 1 The individual responses of the mean arterial blood pressure (MAP) to graded infusion of intravenous dobutamine in four patients are shown.

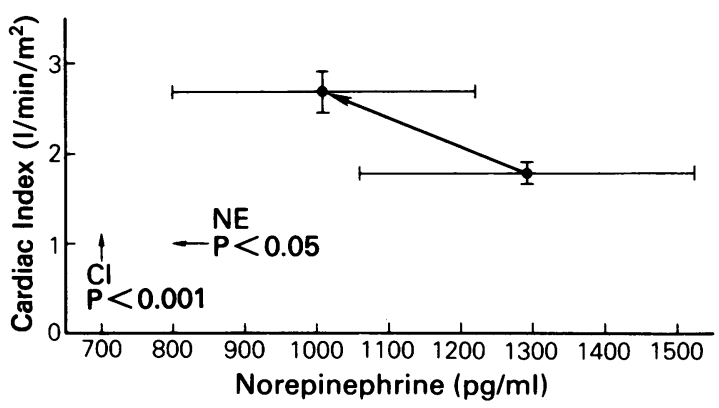

Figure 2 The mean responses of the peak cardiac index and plasma norepinephrine level to a dobutamine infusion in nine patients are shown. The data suggest that with an improvement in cardiac performance by an exogenous sympathomimetic agent, there is a reflex decrease in endogenous sympathetic nervous system activity (as reflected by the plasma norepinephrine level).

Assumption 2 That acute haemodynamic improvement is sustained.

It is now clear that this assumption cannot be accepted without reservation. It would appear that the salutary effects of the beta-adrenergic agonists attenuate over time. Unverferth et al. (1980) have demon-

Table II Acute rest haemodynamic response (\%) to some positive inotropic agents

\begin{tabular}{lll}
\hline Drug & Cardiac output & $\begin{array}{l}\text { Left ventricular } \\
\text { filling pressure }\end{array}$ \\
\hline $\begin{array}{ll}\text { Amrinone } \\
\text { Intravenous } \\
\text { Oral }\end{array}$ & +39 to +50 & -23 to -46 \\
Digoxin & +34 & -26 \\
$\quad$ Oral & +9 to +20 & -6 to -38 \\
$\begin{array}{l}\text { Dobutamine } \\
\text { Intravenous }\end{array}$ & +26 to +69 & -11 to -55 \\
$\begin{array}{l}\text { Dopamine } \\
\text { Intravenous }\end{array}$ & +34 to +70 & +10 to -27 \\
$\begin{array}{l}\text { MDL 17,043 } \\
\text { Intravenous }\end{array}$ & +31 to +82 & -32 to -48 \\
$\quad$ Oral & +37 & -40 \\
$\begin{array}{l}\text { MDL 19,205 } \\
\text { Intravenous }\end{array}$ & +75 & -35 \\
$\begin{array}{l}\text { Milrinone } \\
\text { Intravenous } \\
\text { Oral }\end{array}$ & +33 to +53 & -33 \\
$\begin{array}{l}\text { Pirbuterol } \\
\text { Oral }\end{array}$ & +39 & -27 \\
$\begin{array}{l}\text { Prenalterol } \\
\text { Oral }\end{array}$ & +41 to +50 & -17 to -28 \\
\hline & +41 to +50 & -17 to -38 \\
\hline
\end{tabular}


strated a $30 \%$ attenuation of cardiac output by 72 hours with a constant intravenous dobutamine infusion. Acute improvement in radionuclide ejection fraction with the beta agonist pirbuterol was inapparent by 4 weeks of chronic therapy (Colucci et al., 1981). Three patients studied by us on chronic pirbuterol therapy had a total loss of improvement in cardiac output at 6 week restudy. It should be pointed out that certain other studies (Pamelia et al., 1983; Dawson et al., 1983) have suggested continued haemodynamic efficacy with this agent. The reason for these differences is not clear at this time. Lack of chronic haemodynamic effect has also been observed with the beta agonist prenalterol (Lambert et al., 1984). The loss of responsitivity to beta-1 agonists has been attributed to 'down regulation' of the betareceptor, both in actual number (Colucci et al., 1981; Lefkowitz et al., 1984; Linden et al., 1983) and effective stimulation per receptor (Lefkowitz et al., 1984).

Preliminary data suggest that levodopa may be efficacious in chronically improving cardiac output through endogenous conversion of levodopa to dopamine (Rajfer et al., 1984). The explanation for chronic efficacy is presently not clear but may be related to a catecholamine 'burst' effect which may improve intermittently cardiac output with short 'rest' periods for the beta receptors. Such speculation will require empiric confirmation.

Agents that work through a non-beta-adrenergic mechanism seem to maintain haemodynamic efficacy over a chronic period. These agents include digoxin (Arnold et al., 1980), amrinone (Maskin et al., 1982), milrinone (Maskin et al., 1983a), and MDL 17,043 (Uretsky et al., 1984). As opposed to the beta agonists which appear to exert their inotropic effect through the cell membrane receptor, these agents operate through other mechanisms. The digitalis compounds probably act through the cell membrane sodiumpotassium ATPase pump whereas both amrinone and MDL 17,043 are potent inhibitors of cardiac phosphodiesterase which may be the major mechanism by which these agents work (Kariya et al 1982). Thus, available evidence suggests that inotropic agents which work through a non-beta-adrenergic mechanism may have a sustained effectiveness in the patient with heart failure.

Assumption 3 That functional capacity can be improved.

In studies to evaluate this question, the sympathomimetic agents dobutamine and dopamine have not produced acute improvement in functional capacity (Maskin et al., 1983b, 1983c; Wilson et al., 1984). Neither peak workload nor exercise time has been increased with these agents. At peak exercise, cardiac output was greater than control but systemic arterial venous oxygen difference was more narrow. These data suggest that increased cardiac output at peak exercise may be shunted to non-metabolically active tissues. This shunting may be a consequence of the peripheral vasodilation action of these drugs. Thus, we cannot state with certainty at the present time the effect on functional capacity of cardiac beta stimulation without a vasoactive component.

The ability of non-sympathomimetic agents to enhance exercise performance is also not clear at present. It may be argued that the combined inotropic effects of increased sympathetic stimulation from exercise itself plus stimulation of a second inotropic mechanism such as inhibition of the sodium-potassium ATPase pump (digitalis compounds) or phosphodiesterase inhibition (amrinone, milrinone, MDL 17,043, MDL 19,205, ARL-115-BS) would allow for greater exercise performance. Available data do not support this hypothesis. In a study by Weber $e t$ al. (1981), amrinone did not produce an acute improvement in exercise time and peak oxygen consumption, whereas in a study by Siskind et al. (1981) acute exercise performance was enhanced. Little data is presently available on acute exercise performance with other non-sympathomimetic investigational agents. Although two hundred years have elapsed since digitalis was first used for heart failure, it is unclear if this drug has any effect on acute exercise performance.

The evaluation of a drug via long-term exercise testing requires a control group and a blinding procedure. Results of exercise testing without these precautions are only convincing if exercise results show no change over the control. Under these circumstances, the drug might even be considered detrimental to exercise performance since a 5-20\% improvement in exercise capacity over a 1-3 month follow-up period may be expected from placebo alone (Captopril Multicenter Research Group, 1983). If, on the other hand, exercise performance improves moderately $(>25 \%)$, such results should be considered encouraging but preliminary. Weber et al. (1981) showed a longterm improvement in a small group of patients on amrinone. Leier et al. (1983) in a small group showed such improvement was greater than in a control placebo group. However, in a placebo controlled multicentre, double-blind study, the improvement in exercise performance was no greater than with placebo (DiBianco et al., 1983). At present, placebo-controlled, blinded studies on milrinone and MDL 17,043 currently in progress may help to clarify this issue.

Interestingly, intermittent infusions of intravenous dobutamine given in a blinded manner to ambulatory patients with heart failure have been shown to improve exercise capacity when compared to a placebo group (Leier et al., 1982; Liang et al., 1984). The mechanism by which such an improvement occurs is not clear at 
present, although a peripheral 'drug-induced conditioning' has been suggested (Leier et al., 1982).

Assumption 4 That patients with heart failure will feel better with inotropic therapy.

The evaluation of 'feeling better' is still a problem. The subjectivity on the part of the patient and investigator, and the biases towards improvement, require a control group and a blinding procedure. Nevertheless, studies without these precautions do have some value in that very low improvement rates suggest a drug will have very limited, if any, value in the treatment of heart failure whereas a drug with a very high response rate would appear worthy of a controlled trial. A second problem is related to the classification of symptoms. The New York Heart Association functional classification is discontinuous, that is, patients have to be classified as I, II, III, or IV. In order to show improvement by this scale, a patient must jump an entire class, an infrequent event in patients with severe heart failure. Using this reasoning, those who have expressed symptomatic improvement using the scale as continuous, e.g. adding a decimal to the whole number class, are probably using this classification incorrectly (Captopril Multicenter Research Group, 1983). In truth, however, we frequently consider this classification as continuous (Figure 3). In the example in Figure 3, all three patients improved to a similar degree; however, only patients 1 and 2 showed improvement using this classification. Also, the improvements in patients 1 and 2 tend to be exaggerated using this scale. Another consideration regarding symptomatic change is the time after a drug institution. Placebo effect would tend to be greatest immediately upon starting a drug. Response rates are expected to be highest on drug initiation. Therefore, the longer time a high response rate continues, the more significant it would appear to be. With these considerations, we can review existing data

\begin{tabular}{|c|c|c|c|c|c|}
\hline \multicolumn{2}{|c|}{ Asymptomatic } & $\begin{array}{l}\text { Mildly } \\
\text { Limited }\end{array}$ & $\begin{array}{l}\text { Moderately } \\
\text { Limited }\end{array}$ & $\begin{array}{l}\text { Severely } \\
\text { Limited }\end{array}$ & Incapacitated \\
\hline & 1 & & 11 & III & IV \\
\hline $\begin{array}{l}\text { Patient } \\
\text { Number }\end{array}$ & $\begin{array}{l}\text { NYH } \\
\text { Char }\end{array}$ & $\begin{array}{l}\text { HA } \\
\text { ange }\end{array}$ & & & \\
\hline 1 & $\| 11 \leftarrow \leftarrow$ & & & & \\
\hline 2 & $\| \leftarrow 1$ & & & & \\
\hline 3 & $\| I 1 \leftarrow 1$ & & & & \\
\hline
\end{tabular}

Figure 3 The New York Heart Association symptom classification can be thought of as a continuous or noncontinuous variable, as shown. If thought of as noncontinuous in this example, patients 1 and 2 will show improvement by one class whereas patient 3 will not, although all three have improved by the same amount. related to the ability of an inotropic agent to improve symptomatically patients with chronic heart failure.

Withering's treatise (1941) suggested that the digitalis leaf might be effective therapy for 'dropsy'. This encouraging first report has not been followed up over the past 200 years with a totally convincing controlled, randomized, blinded trial that demonstrates clearly the efficacy of digitalis in patients with heart failure and normal sinus rhythm. Withering's impression that digitalis leaf was effective therapy may have been correct but such an efficacy may have been related to control of the ventricular response in patients with atrial fibrillation. Whether an extract of the digitalis leaf or specific digitalis compounds can improve 'dropsy' independent of the effect on atrial fibrillation is still not clear. Lee et al. (1982) concluded, in a placebo-controlled, double-blind study, that oral digoxin improved ambulatory patients with heart failure particularly if a third heart sound was present. In a recent study by Gheorgiade \& Beller (1983), in which all heart failure patients were in normal sinus rhythm, withdrawal of chronic digoxin therapy to heart failure patients, also on diuretics and in most cases, vasodilators, did not produce any detrimental effects to this group. Recently, a review of studies on digoxin's therapeutic efficacy including the methodological problems in each study has been published (Mulrow et al., 1984). In summary, there is still $\delta$ significant controversy that any digitalis compound as a result of its inotropic action can improve symp-ce tomatically patients with congestive heart failure.

The first published reports in man on the effects of amrinone (Benotti et al., 1978; LeJemtel et al., 1979) occasioned tremendous enthusiasm and expectation in both the medical and lay press. Unfortunately, a large multi-centre placebo-controlled double blinded study (DiBianco et al., 1983) could not demonstrate a therapeutic advantage of amrinone over placebo. It has been suggested that lack of efficacy was related to amrinone's narrow therapeutic:toxic ratio which did not allow for a high enough dose to confer a therapeutic response (Baim et al., 1983). Milrinone, a congener of amrinone, is said to possess a higher therapeutic:toxic ratio. Multicentre, randomized, placebo controlled trials are now in progress with this agent as they are with another phosphodiesterase inhibitor, MDL 17,043. In summary, it may be siad that at present, none of the currently investigational inotropic agents have convincingly shown the ability to symptomatically improve the patient with heart failure. Dobutamine, given as intermittent intravenous infusions over several months, has been shown to improve symptoms concomitant with improvement of functional capacity when compared to a placebo group (Leier et al., 1982a; Liang et al., 1984). It is unlikely that the symptomatic improvement is related only to haemodynamic changes induced by 
dobutamine since patients felt better also during periods between dobutamine infusions. The mechanism by which this improvement occurs is unknown but may be related to a 'conditioning' effect in the periphery (Leier et al., 1982).

Assumption 5 That the effects of an inotropic agent are not deleterious in man.

An inotropic agent may upset the tenuous balance between energy production and utilization (Katz, 1978), causing long-term deleterious effects to the individual myocardial cells. Many mundane, but clear, examples have been offered to express concerns about this form of therapy. An inotropic agent has been compared to whipping a tired horse or racing an older car. Although performance may be better for a short period for the horse or car under the above circumstances, it can be expected that such treatment will ultimately result in a shorter life span for either the car or the horse. To examine whether these analogies are representative of the effects of the inotropic drugs in man, it is worthwhile to review the effects of inotropic agents in experimental preparations and man.

One difficulty in addressing this question is the lack of an acceptable animal model of chronic heart failure. Thus, conclusions on this issue can only be drawn inferentially from acute heart failure models, and other models, both acute and chronic, of ventricular dysfunction, which may not be totally applicable to the human condition. In studies designed to produce an ischaemic myocardium, several inotropic agents including isoproterenol, norepinephrine, and dobutamine have been shown to worsen cardiac performance and to increase infarct size pathologically (Vatner et al., 1974, 1976; Maroko et al., 1971, 1973; Davidson et al., 1974). Early studies suggested that dobutamine increased infarct size (Vatner et al., 1974). In more recent studies, myocardial injury after dobutamine has either been shown not to change (Rude et al., 1982) or decrease (Liang et al., 1981). Discrepancies in results of early $v s$ later studies have been attributed to differences in the heart rate in these studies (Liang et al., 1981; Rude et al., 1984). Chronic catecholamine infusions in certain animal species have produced a type of cardiomyopathy (Lee \& Downing, 1982a; Yates et al., 1981), although the factors producing myocardial injury have not been clarified. Unverferth et al. (1982) have demonstrated potentially therapeutic advantages of a 3 day infusion of dobutamine in patients with severe heart failure. Endomyocardial biopsy specimens showed an improved ATP/creatine ratio compared to pre-infusion suggesting improved health to the individual myocytes.

Is there evidence in man that inotropic therapy is deleterious? It has been suggested that improvement in survival be considered a therapeutic endpoint with inotropic therapy (Braunwald \& Colucci, 1984). We do not believe this finding to be necessary. Rather, we feel it is more appropriate to consider the therapeutic endpoint to be symptomatic improvement without a worsening in survival rate. Thus, we can raise the question of whether inotropic therapy has been shown to worsen survival, or presumably as an intermediate step, worsen long-term cardiac function. At this point, adequate long-term, placebo-controlled, blinded studies have not been performed to address those questions. As such, we can only draw inferences from existing data. As a by-product to long-term haemodynamic evaluation of various vasodilators, baseline haemodynamics at two points in time have been frequently obtained (Chatterjee et al., 1980; Packer et al., 1982; Leier et al., 1983; Kramer et al., 1983). Interestingly, most studies have shown very little difference in the baseline haemodynamics at these two points which have been taken between 12 and 37 weeks apart. Maskin et al. (1982), on the other hand, reported significantly worsened baseline haemodynamics after chronic (approximately 10 months) amrinone use. The authors attributed this worsening to the natural progression of the underlying cardiac disease. It is possible that the worsening may have been due to the unnatural progression related to chronic amrinone use. Recently, Packer et al. (1984) have demonstrated similar findings at 3 months. If amrinone, in fact, caused a deterioration in cardiac function, one might expect an increased mortality compared to that found in natural history studies. Unfortunately, such natural history studies are difficult to evaluate in that regard (Franciosa et al., 1983; Wilson et al., 1983). Differences in patient selection, classification of the severity of heart failure, longevity of the heart failure drug usage, and aetiology of the heart failure make comparison to an historical standard difficult. Packer et al. (1984) using as controls patients referred for vasodilator therapy [either hydralazine (101 patients) or captopril (70 patients)] showed a significantly lower 3-month survival rate $(41 \%)$ with amrinone ( 29 patients) than in either control vasodilator group (65\% with hydralazine, $71 \%$ with captopril). Evidence from our institution demonstrates an overall annual mortality with MDL 17,043 of at least $68 \%$. Although our patients represent an extremely ill group on the whole, it is still unlikely, based on these figures, that MDL 17,043 improved survival and may have, in fact, worsened it (Franciosa et al., 1983; Wilson et al., 1983). Multicentre, controlled, randomized trials currently under way with this agent will hopefully answer this question. Finally, controversy exists even in the potential of digoxin to worsen mortality with data suggesting both a worsening (Moss et al., 1981) and no effect (Ryan et al., 1983) on survival. The data, although suggestive at best, emphasize the need to evaluate mortality in deciding on the propriety of 
inotropic drugs in the heart failure setting.

In summary then, new inotropic therapy offers exciting potential. The available data do not, however, recommend it as a form of therapy until the above assumptions are shown to be true.

\section{References}

ALOUSI, A.A., CANTER, J.M., MONTENARO, M.J., FORT, D.J. \& FERRARI, R.A. (1983). Cardiotonic activity of milrinone, a new and potent cardiac bipyridine, on the normal and failing heart of experimental animals. Journal of Cardiovascular Pharmacology, 5, 792.

ARNOLD, S.B., BYRD, R.C., MEISTER, W., MELMON, K., CHEITLIN, M.D., BRISTOW, J.D., PARMELY, W.W. \& CHATTERJEE, K. (1980). Long-term digitalis therapy improves left ventricular function in heart failure. New England Journal of Medicine, 303, 1443.

BAIM, D.S., MCDOWELL, A.V., CHERNILES, J., MONRAD, E.S., PARKER, J.A., EDELSON, J., BRAUNWALD, E. \& GROSSMAN, W. (1983). Evaluation of a new bipyridine inotropic agent - milrinone - in patients with severe congestive heart failure. New England Journal of Medicine, 309, 748.

BENOTTI, J.R., GROSSMAN, W., BRAUNWALD, E., DAVOLOS, D.D. \& ALOUSI, A.A. (1978). Hemodynamic assessment of amrinone. New England .Journal of Medicine, 299, 1373.

BEREGOVICH, J., BIANCHI, C., RUBLER, S., LOMNITZ, E., CAGIN, N. \& LEVITT, B. (1974). Dose-related hemodynamic and renal effects of dopamine in congestive heart failure. American Heart Journal, 87, 550.

BRAUNWALD, E. \& COLUCCI, W.S. (1984). Evaluating the efficacy of new inotropic agents. (Editorial). Journal of the American College of Cardiology, 3, 1570.

CAPTOPRIL MULTICENTER RESEARCH GROUP. (1983). A placebo controlled trial of captopril in refractory chronic congestive heart failure. Journal of the American College of Cardiology, 2, 755.

CHATTERJEE, K., PORTS, T.A., BRUNDAGE, B.H., MASSIE, B., HOLLY, A.N. \& PARMLEY, W.W. (1980). Oral hydralazine in chronic heart failure: sustained beneficial hemodynamic effects. Annals of Internal Medicine, 92, 600.

COLUCCI, W.S., ALEXANDER, R.W., WILLIAMS, G.H., RUDE, R.E., HOLMAN, B.L., KONSTAM, M.A., WYNN, J., MUDGE, G.H. JR. \& BRAUNWALD. (1981). Decreased lymphocyte beta-adrenergic-receptor density in patients with heart failure and tolerance to the beta-adrenergic agonist pirbuterol. New England Journal of Medicine, 305, 185.

DAVIDSON, S., MAROKO, P.R. \& BRAUNWALD, E. (1974). Effects of isoproterenol on contractile function of the ischemic and anoxic heart. American Journal of Physiology, 227, 439.

DAWSON, J.R., CANEPA-ANSON, R., KUAN, P., REUBEN, S.R., POOLE-WILSON, P.A. \& SUTTON, G.C. (1983). Symptoms, haemodynamics and exercise capacity during long term treatment of chronic heart failure: experience with pirbuterol. British Heart Journal, 50, 282.

\section{Acknowledgements}

I would like to gratefully acknowledge the assistance of Mrs Elsie Eberman, Ms Darlene Thiel, Mr Albert Durica, and Ms Anita Valdes in the preparation of this manuscript. I would also like to acknowledge Dr James A. Shaver for his helpful criticism in the preparation of this manuscript.

DiBIANCO, R., SHABETAI, R., SILVERMAN, B., LEIER, C., BENOTTI, J., SILVERMAN, M.E., STEELE, P., MERRILL, A., WEINSTEIN, N.A., BREHM, J., GERBER, L. \& SINGH, S.N. (1983). Oral amrinone for congestive heart failure: preliminary results of a multicenter, doubleblind and placebo-controlled withdrawal. Journal of the American College of Cardiology, 1, 675 (abst).

FRANCIOSA, J.A., WILEN, M., ZIESCHE, S. \& COHN, J.N. (1983). Survival in men with severe chronic left ventricular failure due to either coronary heart disease or idiopathic dilated cardiomyopathy. American Journal of Cardiology, $51,831$.

GHEORGHIADE, M. \& BELLER, G.A. (1983). Effects of discontinuing maintenance digoxin therapy in patients with ischemic heart disease and congestive heart failure in sinus rhythm. American Journal of Cardiology, 51, 1243.

HOLZER, J., KARLINER, J.S., O'ROURKE, R.A., PITT, W. \& ROSS, J. JR. (1973). Effectiveness of dopamine in patients with cardiogenic shock. American Journal of Cardiology 32, 79.

KARIYA, T., WILLE, L.J. \& DAGE, R.C. (1982). Biochemica studies on the mechanism of cardiotonic activity of MDL 17,043. Journal of Cardiovascular Pharmacology, 4; 509.

KATZ, A.M. (1978). A new inotropic drug: its promise and a caution. (Editorial). New England Journal of Medicine, 299, 1409.

KRAMER, B.I.,' MASSIE, B.M. \& TOPIC, N. (1983). Controlled trial of captopril in chronic heart failure: a rest and exercise hemodynamic study. Circulation, 67, 807.

LAMBERTZ, H., MEYER, J. \& ERBEL, R. (1984). Long-term hemodynamic effects of prenalterol in patients with severe congestive heart faiure. Circulation, 69, 298.

LEE, D.C., JOHNSON, R.A., BINGHAM, J.B., LEAHY, M., DINSMORE, R.E., GOROLL, A.H., NEWELL, J.B., STRAUSS, H.W. \& HABER, E. (1982). Heart failure in outpatients. New England Journal of Medicine, 306, 699.

LEE, D.C. \& DOWNING, S.E. (1982). Ventricular function in norepinephrine-induced cardiomyopathic rabbits. American Journal of Physiology, 242, H191.

LEFKOWITZ, R.J., CARON, M.G. \& STILES, G.L. (1984) Mechanisms of membrane-receptor regulation. New England Journal of Medicine, 310, 1570.

LEIER, C.V., WEBEL, J. \& BUSH, C.A. (1977). The cardiovascular effects of the continuous infusion of dobutamine in patients with severe cardiac failure. Circulation, 56, 468.

LEIER, C.V., HUSS, P., LEWIS, R.P. \& UNVERFERTH, D.V. (1982). Drug-induced conditioning in congestive heart failure. Circulation, 65, 1382.

LEIER, C.V., DALPIAZ, K., HUSS, P., HERMILLER, J.B., MAGORIEN, R.D., BASHORE, T.M. \& UNVERFERTH, D.V. 
(1983). Amrinone therapy for congestive heart failure in outpatients with idiopathic dilated cardiomyopathy. American Journal of Cardiology, 52, 304.

LEIER, C.V., HUSS, P., MAGORIEN, R.D. \& UNVERFERTH, D.V. (1983a). Improved exercise capacity and differing arterial and venous tolerance during chronic isosorbide dinitrate therapy for congestive heart failure. Circulation, 67, 817 .

LEJEMTEL, T.H., KEUNG, E., SONNENBLICK, R.H., RIBNER, H.S., MATSUMOTO, M., DAVIS, R., SCHWARTZ, W., ALOUSSI, A.A. \& DAVOLOS, D. (1979). Amrinone: A new glycosidic, non-adrenergic cardiotonic agent effective in the treatment of intractable myocardial failure in man. Circulation, 59, 1098.

LIANG, C., UI, J.M., SHERMAN, L.G., BLACK, J., GAVRAS, H. \& HOOD, W.B. JR. (1981). Dobutamine infusion in conscious dogs with and without acute myocardial infarction. Circulation Research, 49, 170.

LIANG, C., SHERMAN, L.G., DOHERTY, J.U., WELLINGTON, K., LEE, V.W. \& HOOD, W.B. JR. (1984). Sustained improvement of cardiac function in patients with congestive heart failure after short-term infusion of dobutamine. Circulation, 69, 113.

LIMAS, C.J. \& LIMAS, C. (1983). Involvement of microtubules (MT) in isoproterenol (ISO)-induced "down" regulation of cardiac beta adrenergic receptors. Circulation, 68, 58 (abst).

LINDEN, J. (1983). Acute down-regulation of cardiac betaadrenergic receptor number. Circulation, 68, 57 (abst).

LOEB, H.S., WINSLOW, E.B.J., RAHIMTOOLA, S.H., ROSEN, K.M. \& GUNNAR, R.M. (1971). Acute hemodynamic effects of dopamine in patients with shock. Circulation, 44, 163.

MAROKO, P.R., KJEKSHUS, J.K., SOBEL, R.E., WATANABE, T., COVELL, J.W., ROSS, J. JR. \& BRAUNWALD, E. (1971). Factors influencing infarct size following experimental coronary artery occlusions. Circulation, 43, 67.

MAROKO, P.R., LIBBY, P. \& BRAUNWALD, E. (1973). Effect of pharmacologic agents on the function of the ischemic heart. American Journal of Cardiology, 32, 930.

MASKIN, C.S., FORMAN, R., KLEIN, N.A., SONNENBLICK, E.H. \& LEJEMTEL, T.H. (1982). Long-term amrinone therapy in patients with severe heart failure. American Journal of Medicine, 72, 113.

MASKIN, C.S., SINOWAY, L., CHADWICK, B., SONNENBLICK, F.H., LEJEMTEL, T.H. (1983a). Sustained hemodynamic and clinical effects of a new cardiotonic agent, WIN 47203, in patients with severe congestive heart failure. Circulation, 67, 1065.

MASKIN, C.S., FORMAN, R., SONNENBLICK, E.H., FRISHMAN, W.H., LEJEMTEL, T.H. (1983b). Failure of dobutamine to increase exercise capacity despite hemodynamic improvement in severe chronic heart failure. American Journal of Cardiology, 51, 177.

MASKIN, C.S., KUGLER, J., SONNENBLICK, E.H. \& LEJEMTEL, T.H. (1983c). Acute inotropic stimulation with dopamine in severe congestive heart failure: Beneficial hemodynamic effect at rest but not during maximal exercise. American Journal of Cardiology, 52, 1028.

MASON, D.T. (1974). Digitalis pharmacology and therapeutics: recent advances. Annals of Internal Medicine, 80,520 .

MOSS, A.J., DAVIS, H.T., CONARD, D.L., DECAMILLA, J.J. \& ODOROFF, C.L. (1981). Digitalis-associated cardiac mor- tality after myocardial infarction. Circulation, 64, 1150.

MULROW, C.D., FEUSSNER, J.R. \& VELEZ, R. (1984). Reevaluation of digitalis efficacy. Annals of Internal Medicine, 101, 113.

PACKER, M., MELlER, J., MEDINA, N., YUSHAK, M. \& GORLIN, R. (1982). Hemodynamic characterization of tolerance to long-term hydralazine therapy in severe chronic heart failure. New England Journal of Medicine, 306, 57.

PACKER, M., MEDINA, N. \& YUSHAK, M. (1985). Failure of low doses of amrinone to produce sustained hemodynamic improvement in patients with severe chronic congestive heart failure. American Journal of Cardiology, 54, 1025.

PAMELIA, F.X., GHEORGHIADE, M., BELLER, G.A., BISHOP, H.L., OLUKOTUN, A.Y., TAYLOR, C.R., WATSON, D.D., GRUNWALD, A.M., SIROWATKA, J. \& CARABELLO, B.A. (1983). Acute and long-term hemodynamic effects of oral pirbuterol in patients with chronic severe congestive heart failure: Randomized double-blind trial. American Heart Journal, 106, 1369.

PETEIN, M., LEVINE, T.B. \& COHN, J. (1984). Hemodynamic effects of a new inotropic agent, piroximone (MDL 19205), in patients with chronic heart failure. Journal of the American College of Cardiology, 4, 364.

RAJFER, S.I., ANTON, A.H., ROSSEN, J.D. \& GOLDBERG, L.I. (1984). Beneficial hemodynamic effects of oral levodopa in heart failure. New England Journal of Medicine, 310, 1357.

RENARD, M., JACOBS, P., DECHAMPS, P., DRESSE, A. \& BERNARD, R. (1983). Hemodynamic and clinical response to three-day infusion of sulmazol (AR-L $115 \mathrm{BS}$ ) in severe congestive heart failure. Chest, 84, 408.

ROSS, G., DABESTANI, A. \& PATEL, A.L. (1981). Effects of amrinone on vascular smooth muscle. Federation Proceedings, 40, 659 (abst).

RUDE, R.E., IZQUIERDO, C., BUJA, L.M. \& WILLERSON, J.T. (1982). Effects of inotropic and chronotropic stimuli on acute myocardial ischemic injury. Circulation, 65, 1321.

RUDE, R.E., BUSH, L.R., IZQUIERDO, C., BUJA, L.M. \& WILLERSON, J.T. (1984). Effects of inotropic and chronotropic stimuli on acute myocardial ischemic injury. American Journal of Cardiology, 53, 1688.

RUFFOLO, R.R. JR., SPRADLIN, T.A., POLLOCK, G.D., WADDELL, J.E. \& MURPHY, P.J. (1981). Alpha and beta adrenergic effects of the stereoisomers of dobutamine. Journal of Pharmacology and Experimental Therapeutics, 219, 447.

RYAN, T.J., BAILEY, K.R., MCCABE, C.H., LUK, S., FISHER, L.D., MOCK, M.B. \& KILLIP, T. (1983). The effect of digitalis on survival in high-risk patients with coronary artery disease. Circulation, 67, 735.

SINOWAY, L.S., MASKIN, C.S., CHADWICK, B., FORMAN, R., SONNENBLICK, E.H. \& LEJEMTEL, T.H. (1983). Long-term therapy with a new cardiotonic, WIN 47203: Drug-dependent improvement in cardiac performance and progression of the underlying disease. Journal of the American College of Cardiology, 2, 327.

SISKIND, S.J., SONNENBLICK, E.H., FORMAN, R., SCHEUR, J. \& LEJEMTEL, T.H. (1981). Acute substantial benefit of inotropic therapy with amrinone on exercise hemodynamics and metabolism in severe congestive heart failure. Circulation, 64, 966.

THORMANN, J., KRAMER, W. \& SCHLEPPER, M. (1982). Hemodynamic and myocardial energetic changes induced 
by the new cardiotonic agent, AR-L 115, in patients with coronary artery disease. American Heart Journal, 104, 1294.

UNVERFERTH, D.V., BLANDFORD, M. KATES, R.E. \& LEIER, C.V. (1980). Tolerance to dobutamine after a 72 hour continuous infusion. American Journal of Medicine, 69, 262.

UNVERFERTH, D.V., MAGORIEN, R.D., ALTSCHULD, R., KOLIBASH, A.J., LEWIS, R.P. \& LEIER, C.V. (1982). The hemodynamic and metabolic advantages gained by a three-day infusion of dobutamine in patients with congestive cardiomyopathy. American Heart Journal, 106, 29.

URETSKY, B.F., GENERALOVICH, T., REDDY, P.S., SPANGENBERG, R.B. \& FOLLANSBEE, W.P. (1983). The acute hemodynamic effects of a new agent, MDL 17,043, in the treatment of congestive heart failure. Circulation, 67, 823.

URETSKY, B.F., GENERALOVICH, T., SPANGENBERG, R. REDDY, P.S., VALDES, A., SALERNI, R. (1984). The acute and chronic response to oral MDL 17,043 in patients with severe heart failure. Journal of the American College of Cardiology, 3, 562 (abst).

VAN BREEMEN, C., AARONSON, P., LOUTZENHISER, R. \& MEISHERI, K. (1980). $\mathrm{Ca}^{2+}$ movements in smooth muscle. Chest, 78, 157.

VATNER, S.F., MCRITCHIE, R.J., MAROKO, P.R., PATRICK, T.A. \& BRAUNWALD, E. (1974). Effects of catecholamines, exercise and nitroglycerin on the normal and ischemic myocardium in conscious dogs. Journal of Clinical Investigation, 54, 563.
VATNER, S.F., MILLARD, R.W., PATRICK T.A. \& HEYNDRICKX, G.R. (1976). Effects of isoproterenol on regional myocardial function, electrogram and blood flow in conscious dogs with myocardial ischemia. Journal of Clinical Investigation, 57, 1261.

WEBER, K.T., ANDREWS, V., JANICKI, J.S., WILSON, J.R. \& FISHMAN, A.P. (1981). Amrinone and exercise performance in patients with chronic heart failure. American Journal of Cardiology, 48, 164.

WILSON, J.R., SCHWARTZ, J.S., SUTTON, M.S.J., FERRARO, N., HOROWITZ, L.N., REICHEK, N. \& JOSEPHSON, M.E. (1983). Prognosis in severe heart failure: relation to hemodynamic measurements and ventricular ectopic activity. Journal of the American College of Cardiology, 2, 403.

WILSON J.B., MARTIN J.L. \& FERRARO, N. (1984). Impaired skeletal muscle nutritive flow during exercise in patients with congestive heart failure: Role of cardiac pump dysfunction as determined by the effect of dobutamine. American Journal of Cardiology, 53, 1308.

WITHERING, W. (1941). In Cardiac Classics, Willius, F.A. \& Keys, T.E. (eds). p. 1. C.V. Mosby: New York.

YATES, J.C., BEAMISH, R.E. \& DHALLA, N.S. (1981). Ventricular dysfunction and necrosis produced by adrenochrome metabolite of epinephrine: relation to pathogenesis of catecholamine cardiomyopathy. American Heart Journal, 102, 210. 